\title{
Morphological and Microsatellite Marker Analysis of Fruit Size and Shape in Selected Accessions and Commercial Cultivars of Capsicum Species in Sri Lanka
}

\author{
${ }^{1} \mathrm{M}$ D M. Chamikara, ${ }^{1} \mathrm{M}$ Ishan, ${ }^{1} \mathrm{~S}$ S Karunadasa, ${ }^{1} \mathrm{M}$ K D I Perera, ${ }^{1} \mathrm{P}$ I Rajapaksha, \\ ${ }^{1} \mathrm{R}$ V Lelwala, ${ }^{1} \mathrm{~V}$ D W Kasthuriarachchi, ${ }^{1} \mathrm{D} \mathrm{T}$ Jeyakumar, ${ }^{2} \mathrm{C} \mathrm{K}$ Weebadde \\ and ${ }^{1}$ S D S S Sooriyapathirana
}

\begin{abstract}
${ }^{1}$ Department of Molecular Biology and Biotechnology, Faculty of Science, University of Peradeniya, Sri Lanka

${ }^{2}$ Department of Plant, Soil and Microbial Sciences, College of Agriculture and Natural Resources, Michigan State University, East Lansing, MI, USA
\end{abstract}

\begin{abstract}
Chili pepper (Capsicum spp.)is a vegetable crop with medical and ornamental uses. In Sri Lanka, 56\% of dried chili is imported annually making it a huge burden to the economy. To improve the chili pepper industry, breeding could be suggested as one of the strategies. With the advancement of Molecular Biology, breeding is now practiced with marker assisted selection. According to the present knowledge, no such breeding programs are taking place in Sri Lanka. Therefore the objectives of the present study were to characterize the morphology and validate fruit size and shape linked microsatellite markers using an ex situ Capsicum collection in comparison to the commercial cultivars. The accessions and cultivars were established in a greenhouse at Peradeniya, Sri Lanka. Leaf and fruit morphological data were recorded at flowering and fruit maturity respectively. Five microsatellite markers (HpmsE045, CAeMSO10, GPMS178, CAMS451 and CAMS493) were used to genotype all 49 accessions using PCR and bands were size separated using polyacrylamide gel electrophoresis. According to the fruit shape, six groups were identified namely Triangular, Elongated long, Elongated short, Spherical sharp-end, Spherical blunt-end and Rectangular. The plant height had a negative correlation with the number of fruits of the plant at first harvest. Number of seeds per fruit and the fruit diameter were significantly associated with the fruit weight $(P<0.05)$. Microsatellite marker analysis revealed 44 alleles explaining very high level of genetic diversity (in the range of $62 \%$ to $87 \%$ ). Out of the 44 alleles, 15 alleles were found to be significantly affecting on fruit size traits and 23 alleles were associated with fruit shape. This validated marker information could be used to plan future breeding programs and genetic studies for chili pepper.
\end{abstract}

KEYWORDS: QTL, genetic diversity, morphological diversity, chili pepper, Capsicum. Corresponding author: S.D.S.S. Sooriyapathirana, email: sunethss09@gmail.com 


\section{INTRODUCTION}

Chili pepper, Capsicum spp. ( $2 \mathrm{n}=24)$, is one of the most significant crops with very high economic importance (Shih-Wen et al., 2013; Department of Agriculture, Sri Lanka, 2007; Dahal et al., 2006). Genus Capsicum contains approximately 32 species (Moscone et al., 2007), however, $C$. annuum, $C$. chinense and $C$. frutescens are the key species for human consumption. These species were domesticated in 6000 BC (Perry et al., 2007). There are records explaining the pre-Colombian use of $C$. annuum and $C$. frutescens in Mexico (Perry and Flannery, 2007). Kraft et al., (2014) argued that the domestication of chili pepper was taken place in Mexico. Chili pepper could be pungent or sweet. Pungent chili pepper is used as a spice, herbal medicine and ornamental plants (Hayman and Kam, 2008; Monteiro et al., 2013) and sweet pepper is used as a vegetable (Bosland and Votava, 2012). In the world, nearly 35 million tons of fresh fruits and 3.5 million tons of dry fruits of chili pepper are being consumed annually (FAO, 2014). Chili pepper fruits are extremely rich in compounds such as carotenoids, ascorbic acid, tocopherols, capsaicinoids and flavonoids which have medicinal and nutritional values (Rosa et al., 2013; Martí et al., 2011).

In Sri Lanka, $56 \%$ of the dried chili (amount equivalent to approximately 31,000 tons) requirement is imported annually. There are five recommended chili varieties in Sri Lanka (Department of Agriculture, Sri Lanka, 2007) but chili farming has to be improved to meet the country's requirement. Breeding with existing genetic diversity, which utilizes the genomic information available internationally, must be practiced in order to achieve high genetic gains in quick time with very high accuracy. According to the present knowledge such molecular breeding programs for chili improvement is not taking place in Sri Lanka.

However with the rapid advancement of molecular biological techniques, a wealth of genomic information on chili pepper is coming from many parts of the world. The chili pepper genome sequence is now available providing a detailed insight of important genes in the genome (Qin et al., 2014). Wang and Bosland, (2006) has published an updated list of 292 genes coding for traits such as male sterility, resistance to nematodes, diseases and herbicides. For these genes, molecular markers and chromosomal locations are also available enabling world-wide breeders to undertake their programs swiftly. Based on WRKY genes, molecular markers were developed flanking their conserved sequences (Kim et al., 2008) and they can be used in marker assisted selection as well. Quantitative trait loci (QTL) analyses were conducted on many important traits in chili pepper such as capsaicinoid biosynthesis (Blum et al., 2003), fruit length (Lee et al., 2011), cucumber mosaic virus resistance (Yao et al., 2013), anthracnose resistance (Kim et al., 2010), fruit traits (Marame et al., 2009) and fruit diameter, length and shape (Mimura et al., 2012). Chili pepper fruit morphological traits are having high heritability (Usman et al., 2014) enabling very high gains in breeding.

In addition, genetic variations of fruit traits (Schuelter et al., 2010) in Brazilian Capsicum germplasm (Sudré et al., 2007) and in Peruvian Capsicum germplasm (Meckelmann et al., 2013) were explained. Similarity, for ex situ and in situ chili pepper populations (Votava et al., 2002), the applicability of microsatellite markers for the assessment of genetic diversity (PachecoOlvera et al., 2012) were also explained. Various molecular markers have been designed for other practical applications of chili pepper such as Randomly Amplified Polymorphic DNA (RAPD) and Sequence Characterized Amplified Region (SCAR) markers for hybrid purity testing (Jang et al., 2004), SCAR markers for identifying cytoplasmic male sterile plants (Kim and Kim, 2005) and SCAR markers for adulterant detection in chili powder (Dhanya and Sasikumar, 2010). 
However, in Sri Lanka, none of these molecular details are being used for improvement of chili pepper crop. To use this information in routine breeding programs, first the QTL flanking markers must be validated for their segregation and trait-associatedpolymorphism for the local germplasm. According to the present knowledge no such attempts are currently underway for chili pepper breeding in Sri Lanka. Therefore the objectives of present study were to characterize the morphology and validate the fruit size and shape linked microsatellite markers (Mimura et al., 2012) using an Ex situ collection of Capsicum spp. in comparison to a six recommended varieties of chili pepper in Sri Lanka.

\section{MATERIALS AND METHODS}

\section{Plant material}

Mature seeds from 43 wild chili pepper accessions established in a farmer owned $E x$ situ collection at Viskamgama in Rathnapura District, Sri Lanka (Global Positioning System Coordinates: N 60 32' 31.7"; E 800 22' 16.6") and from six commercial chili pepper cultivars (Mi-Hot, Mi-2, Ka-2, Waraniya, Ca-8 and Bellpepper) available in the Seed Center at Department of Agriculture, Sri Lanka were collected in May, 2014 (Accessions and cultivars are collectively referred to as genotypes here after). Nurseries for all collected seeds were established at the Greenhouse in the Department of Molecular Biology and Biotechnology, Faculty of Science, University of Peradeniya, Sri Lanka. After one month of establishment, in the same Greenhouse, four plants from each genotype were transplanted on to pots with $20 \mathrm{~L}$ capacity, containing soil mixture with $40 \%$ natural compost mixture. Standard management practices were followed throughout the growth period as recommended by Department of Agriculture, Sri Lanka (www.agridept.gov.lk).

\section{Morphological measurements}

Height of each plant was measured at the mature stage using a meter ruler from the pot surface to the top tip of the plant canopy. At the same stage of plant height measurement, leaf size measurements (length, breadth and petiole length), shape, margin, base, tip and color of the leaf at completed growth [with reference to the Color Chart available at Vejdemo-Johansson et al., (2014)] were recorded from four independent leaves per plant. At complete maturity, fruit size measurements (length, diameter and weight), shape group according to a scheme (Figure 1) modified from Nicolai et al., (2013), color at maturity and orientation were recorded from four independent fruits per plant. Number of fruits per plant, yield at first harvest (fresh weight basis) and number of seeds per fruit were also recorded.

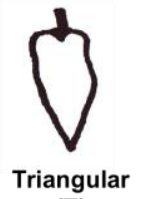

(T)

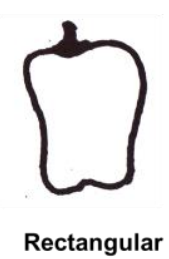

(R)

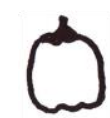

Spherical blunt-end (SB)

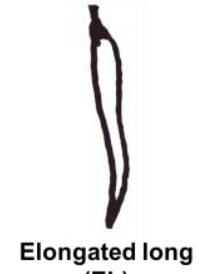

(EL)

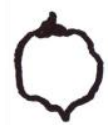

Spherical sharp-end (SS)

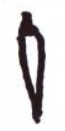

Elongated short (ES)
Figure 1. Illustrations of the fruit shape groups [modified from Nicolai et al., (2013) for the studied germplasm]. Abbreviations are given within parenthesis.

\section{DNA marker analysis}

DNA was extracted using Dneasy ${ }^{\circledR}$ plant mini kit (Qiagen, Solna, Sweden) and stored at $-20{ }^{\circ} \mathrm{C}$. Polymerase Chain Reaction (PCR) was conducted using five microsatellite markers that were reported to be linked with the 
QTL detected for fruit shape and size (Table 1) (Mimura et al., 2012). DNA amplification was performed in $15 \mu \mathrm{l}$ reactions containing $1 \times$ GoTaq ${ }^{\circledR}$ Green Master Mix (Promega Corporation, Madison, Wisconsin, USA), 0.5 $\mu \mathrm{M}$ each of forward and reverse primers and $1.5 \mu \mathrm{l}$ of DNA template $(60 \mathrm{ng} / \mu \mathrm{l})$. Amplifications were carried out using a Thermal Cycler (Takara, Japan) using the PCR cycle: Initial denaturation: $5 \mathrm{~min}$ at $94{ }^{\circ} \mathrm{C} ; 35$ cycles of $30 \mathrm{sec}$ at $94{ }^{\circ} \mathrm{C}, 1.5 \mathrm{~min}$ at annealing temperature (Table 1), $2.5 \mathrm{~min}$ at $72{ }^{\circ} \mathrm{C}$; and a final extension step of $10 \mathrm{~min}$ at $72{ }^{\circ} \mathrm{C}$. All the PCR products were subjected to $6 \%$ denaturing Polyacrylamide Gel Electrophoresis (PAGE) (Sambrook and Russel, 2001) and bands (i.e. alleles) with approximate base pair sizes were reported for each accession / cultivar. The alleles were considered and scored as Single Dose Restriction Fragments (SDRF) (Wu et al., 1992) as for most of the markers more than two alleles were detected making it not possible to call for diploid genotypes.

Table 1. Annealing temperatures and linked fruit traits of microsatellite markers used

\begin{tabular}{|c|c|c|}
\hline Marker & $\begin{array}{c}\text { Linked fruit } \\
\text { trait QTL }\end{array}$ & $\mathbf{T}_{\mathbf{a}}$ \\
\hline HpmsE045 & Length & 58 \\
\hline GPMS178 & Diameter & 55 \\
\hline CAMS451 & Diameter & 55 \\
\hline CAeMS010 & Diameter & 58 \\
\hline CAMS493 & Shape & 53 \\
\hline
\end{tabular}

(Source: Mimura et al., 2012), $\mathrm{T}_{\mathrm{a}}$ : primer annealing temperature $\left({ }^{\circ} \mathrm{C}\right)$

\section{Data analysis \\ Morphological measurements}

The quantitative data were analyzed using the GLM procedure in SAS version 9.1 (SAS Institute Cary, NC, USA). Pearson's correlation coefficients among quantitative parameters were calculated using CORR procedure in SAS. Cluster analysis and the construction of dendrogram were conducted using the algorithms of Average Linkage and Pearson Distance in Minitab 14 (Minitab Inc., USA) using Principal Components which were calculated based on fruit length, diameter, weight and shape.

\section{Marker polymorphisms and their relationships to fruits traits}

Allele frequency (Pi), unique alleles (UA): present only in a single genotype, rare alleles (RA): Pi was equal to or less than $5 \%$ and frequent alleles (FA): $\mathrm{Pi}$ is greater than 5\% were identified for each microsatellite marker. Allele diversity for each marker was calculated in terms of Heterozygosity (H) (Botstein et al., 1980) and Polymorphic Information Content (PIC) (Shete et al., 2000). The $\mathrm{H}$ and PIC values were calculated for each microsatellite marker using an online PIC calculator available at www.georgikon.hu/pic (Nagy et al., 2012). The $\mathrm{H}$ and PIC are given by the following equations.

$$
\begin{aligned}
& H=1-\sum_{i=1}^{n} P i^{2} \\
& P I C=1-\sum_{i=1}^{n} P i^{2}-\left[\sum_{i=1}^{n-1} \sum_{j=i+1}^{n} P i^{2} P j^{2}\right]
\end{aligned}
$$

$\mathrm{n}=$ Number of alleles

$\mathrm{Pi}=$ Frequency of $i^{\text {th }}$ allele

The significant relationships between the allele data of the microsatellite markers with fruit length and diameter were tested using Single Marker Analysis (GLM Procedure in SAS was employed) for QTL mapping (Liu, 1998). The significant associations between the allele data of the microsatellite markers with the fruit shape were tested using Chi Square Analysis (FREQ procedure in SAS). Cluster analysis and the construction of dendrogram were conducted using the algorithms of Average Linkage and Pearson Distance in 
Minitab 14 (Minitab Inc., USA) using the binary data of the presence / absence of the alleles with significant effect or significant association on fruit size traits.

\section{RESULTS}

\section{Plant height}

The mean plant heights (MPH) at maturity were compared among genotypes and among the set of genotypes, belonged to each fruits shape groups. MPH for each genotype and MPH and standard deviation for the plants belonged to each fruit shape group, are shown in Table 2. In general, the genotypes belonged to Elongated short fruit shape group were taller (MPH was $104.7 \mathrm{~cm}$ ) compared to that of other fruit shape groups. On average, the mean $\mathrm{MPH}$ for the studied germplasm was $80.7 \mathrm{~cm}$ with the standard deviation of $22.2 \mathrm{~cm}$. The taller plants had significantly less number of fruits than that of shorter plants $(P<0.05)$ and four main plant height groups were identified with respect to the variation of fruit set (Figure 2).

\section{Leaf morphology}

The mean leaf length, breadth of widest point and petiole length were significantly different among accessions. However, when leaf shape and size parameters were pooled together for fruit shape groups, they were not significantly different $(P<0.05)$ (Figure 3 of Annexure 2). The leaf shape, margin, base, color and tip of each genotype are given in Table 3. The leaf shape was mainly ovate or lanceolate and rarely triangular (in one genotype); the leaf margin was mainly entire and rarely crenate (in two genotypes); the leaf base was truncate, attenuate or oblique; the leaf tip was acuminate, cuspidate or acute. The leaves of the genotype SS7 was colored with purple pigments (I37) where other accessions / cultivars were green colored G14, F14, H14 or I15 (the color of leaves are given in Figure 3 of Annexure 2).

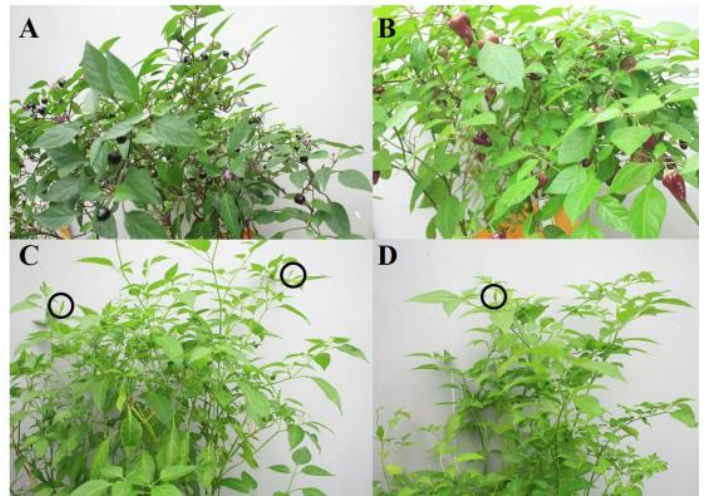

Figure 2. The variability of fruit set in chili pepper genotypes belonged to different plant height groups. $A \rightarrow D$ are the four plant height classes; A: $40-60 \mathrm{~cm}, \mathrm{~B}: 60-80 \mathrm{~cm}, \mathrm{C}: 80-100$ $\mathrm{cm}, \mathrm{D}:>100 \mathrm{~cm}$. Note that shorter plants were having more fruits (A \& B) and taller plants that were having less fruits $(\mathrm{C} \& \mathrm{D})$. In $\mathrm{C}$ and $\mathrm{D}$ circles are used to highlight the fruits as they were not very visible. To show the fruits clearly, photographs were taken closely so that equal portions of the canopies are displayed. All 49 accessions studied showed these kinds of fruit sets with respect to their plant height.

Leaf length and leaf breadth were highly correlated (Pearson Correlation Coefficient was 0.87 at $P<0.0001$ ). Leaf petiole length was also significantly correlated with leaf length and leaf breadth separately. But the strength of correlation was approximately $50 \%$ (Table 4).

\section{Fruit morphology}

In the studied set of Capsicum germplasm, six main fruit shape groups were identified. This classification scheme of fruit shapes into different groups was modified from the scheme explained originally by Nicolai et al., (2013).

Fourteen genotypes were having triangular fruits, six genotypes were having spherical blunt-end fruits, eight genotypes were having spherical sharp-end fruits, two genotypes were having rectangular fruits, 11 genotypes were 
having elongated fruits and eight genotypes Annexure 2). were having elongated short fruits (Figure 4 of

Table 2. Mean plant height of Capsicum genotypes belonged to six fruit shape groups

\begin{tabular}{|c|c|c|c|}
\hline Fruit shape group & Genotype & $\begin{array}{l}\text { Mean plant height at } \\
\text { maturity }(\mathbf{c m})\end{array}$ & $\begin{array}{c}\text { Mean plant height and standard } \\
\text { deviation }(\mathrm{cm})\end{array}$ \\
\hline \multirow{14}{*}{ Triangular (T) } & $\mathrm{T} 1$ & 96.3 & \multirow{14}{*}{$85.2 \pm 20.0$} \\
\hline & $\mathrm{T} 2$ & 104.3 & \\
\hline & T3 & 93.6 & \\
\hline & T4 & 98.7 & \\
\hline & $\mathrm{T} 5$ & 79.0 & \\
\hline & $\mathrm{T} 6$ & 102.5 & \\
\hline & $\mathrm{T} 7$ & 62.4 & \\
\hline & T8 & 59.7 & \\
\hline & T9 & 98.7 & \\
\hline & $\mathrm{T} 10$ & 60.1 & \\
\hline & T11 & 82.6 & \\
\hline & T12 & 77.5 & \\
\hline & T13 & 56.6 & \\
\hline & T14 & 120.9 & \\
\hline \multirow{6}{*}{ Spherical blunt-end (SB) } & SB1 & 74.7 & \multirow{6}{*}{$61.1 \pm 14.2$} \\
\hline & SB2 & 64.8 & \\
\hline & SB3 & 42.5 & \\
\hline & SB4 & 58.5 & \\
\hline & SB5 & 71.3 & \\
\hline & SB6 & 54.6 & \\
\hline \multirow{8}{*}{ Spherical sharp-end (SS) } & SS1 & 56.3 & \multirow{8}{*}{$64.1 \pm 15.3$} \\
\hline & SS2 & 61.2 & \\
\hline & SS3 & 80.3 & \\
\hline & SS4 & 82.8 & \\
\hline & SS5 & 78.3 & \\
\hline & SS6 & 63.6 & \\
\hline & SS7 & 50.0 & \\
\hline & SS8 & 40.3 & \\
\hline \multirow{2}{*}{ Rectangular (R) } & R1 & 90.8 & \multirow{2}{*}{$73.2 \pm 24.9$} \\
\hline & Bell-pepper $^{\mathrm{a}}$ & 55.6 & \\
\hline \multirow{11}{*}{ Elongated long (EL) } & EL1 & 118.0 & \multirow{11}{*}{$81.5 \pm 21.4$} \\
\hline & EL2 & 111.4 & \\
\hline & EL3 & 98.3 & \\
\hline & EL4 & 84.0 & \\
\hline & EL5 & 59.1 & \\
\hline & EL6 & 89.0 & \\
\hline & $M i-2^{\mathrm{a}}$ & 67.8 & \\
\hline & $\mathrm{Mi}-\mathrm{Hot}^{\mathrm{a}}$ & 74.0 & \\
\hline & $K a-2^{\mathrm{a}}$ & 54.5 & \\
\hline & $C a-8^{\mathrm{a}}$ & 57.9 & \\
\hline & Waraniya $^{\mathrm{a}}$ & 82.5 & \\
\hline \multirow{8}{*}{ Elongated short (ES) } & ES1 & 120.8 & \multirow{8}{*}{$104.7 \pm 13.8$} \\
\hline & ES2 & 102.2 & \\
\hline & ES3 & 128.9 & \\
\hline & ES4 & 98.9 & \\
\hline & ES5 & 102.5 & \\
\hline & ES6 & 90.6 & \\
\hline & ES7 & 104.6 & \\
\hline & ES8 & 89.0 & \\
\hline \multicolumn{3}{|c|}{ Mean plant height } & $80.7 \pm 22.2$ \\
\hline
\end{tabular}

${ }^{a}$ Commercial chili pepper cultivars in Sri Lanka 
Table 3. Qualitative parameters of leaf morphology in Capsicum genotypes

\begin{tabular}{|c|c|c|c|c|c|c|}
\hline Fruit shape group & Genotype & Shape & Margin & Base & Tip & Color \\
\hline \multirow{14}{*}{ Triangular $(\mathrm{T})$} & T1 & $\mathrm{OV}$ & $\mathrm{EN}$ & $\mathrm{TN}$ & $\mathrm{AM}$ & G14 \\
\hline & T2 & $\mathrm{OV}$ & EN & $\mathrm{TN}$ & $\mathrm{AM}$ & G14 \\
\hline & T3 & $\mathrm{OV}$ & EN & $\mathrm{TN}$ & $\mathrm{CU}$ & G14 \\
\hline & T4 & $\mathrm{OV}$ & EN & $\mathrm{TN}$ & $\mathrm{AM}$ & G14 \\
\hline & T5 & $\mathrm{OV}$ & EN & $\mathrm{TN}$ & $\mathrm{AM}$ & G14 \\
\hline & T6 & $\mathrm{OV}$ & EN & AT & $\mathrm{CU}$ & G14 \\
\hline & T7 & OV & EN & AT & $\mathrm{AM}$ & G14 \\
\hline & T8 & $\mathrm{OV}$ & $\mathrm{EN}$ & $\mathrm{TN}$ & $\mathrm{AM}$ & F14 \\
\hline & T9 & $\mathrm{OV}$ & $\mathrm{EN}$ & $\mathrm{AT}$ & $\mathrm{AM}$ & G14 \\
\hline & T10 & $\mathrm{OV}$ & EN & $\mathrm{TN}$ & $\mathrm{AM}$ & G14 \\
\hline & T11 & $\mathrm{OV}$ & $\mathrm{CR}$ & $\mathrm{TN}$ & $\mathrm{AM}$ & G14 \\
\hline & T12 & LA & EN & $\mathrm{AT}$ & $\mathrm{CU}$ & G14 \\
\hline & T13 & LA & $\mathrm{EN}$ & AT & $\mathrm{CU}$ & G14 \\
\hline & T14 & TR & $\mathrm{CR}$ & $\mathrm{TN}$ & $\mathrm{CU}$ & G14 \\
\hline \multirow{6}{*}{ Spherical blunt-end (SB) } & SB1 & LA & EN & AT & $\mathrm{CU}$ & G14 \\
\hline & SB2 & LA & EN & AT & AM & G14 \\
\hline & SB3 & LA & $\mathrm{EN}$ & AT & $\mathrm{CU}$ & G14 \\
\hline & SB4 & OV & EN & AT & AM & G14 \\
\hline & SB5 & $\mathrm{OV}$ & EN & AT & $\mathrm{AM}$ & G14 \\
\hline & SB6 & LA & EN & AT & $\mathrm{CU}$ & G14 \\
\hline \multirow{8}{*}{ Spherical sharp-end (SS) } & SS1 & $\mathrm{OV}$ & EN & $\mathrm{AT}$ & $\mathrm{CU}$ & G14 \\
\hline & SS2 & OV & EN & TN & $\mathrm{CU}$ & G14 \\
\hline & SS3 & $\mathrm{OV}$ & EN & TN & $\mathrm{AM}$ & G14 \\
\hline & SS4 & LA & EN & AT & $\mathrm{CU}$ & G14 \\
\hline & SS5 & $\mathrm{OV}$ & EN & $\mathrm{TN}$ & $\mathrm{CU}$ & G14 \\
\hline & SS6 & LA & $\mathrm{CR}$ & AT & $\mathrm{CU}$ & G14 \\
\hline & SS7 & $\mathrm{OV}$ & EN & $\mathrm{AT}$ & $\mathrm{CU}$ & $\mathrm{I} 37$ \\
\hline & SS8 & LA & EN & AT & $\mathrm{CU}$ & H14 \\
\hline \multirow{2}{*}{ Rectangular (R) } & $\mathrm{R} 1$ & LA & $\mathrm{EN}$ & AT & $\mathrm{AM}$ & G14 \\
\hline & Bell-pepper ${ }^{\mathrm{a}}$ & LA & $\mathrm{EN}$ & $\mathrm{AT}$ & $\mathrm{CU}$ & G14 \\
\hline \multirow{11}{*}{ Elongated long (EL) } & EL1 & $\mathrm{OV}$ & EN & AT & $\mathrm{AM}$ & $\mathrm{H} 14$ \\
\hline & EL2 & $\mathrm{OV}$ & $\mathrm{EN}$ & AT & $\mathrm{CU}$ & G14 \\
\hline & EL3 & LA & EN & $\mathrm{AT}$ & $\mathrm{CU}$ & G14 \\
\hline & EL4 & LA & EN & AT & $\mathrm{CU}$ & G14 \\
\hline & EL5 & LA & $\mathrm{EN}$ & $\mathrm{AT}$ & $\mathrm{AM}$ & G14 \\
\hline & EL6 & LA & EN & $\mathrm{AT}$ & $\mathrm{AM}$ & F14 \\
\hline & $M i-2^{\mathrm{a}}$ & $\mathrm{OV}$ & $\mathrm{EN}$ & $\mathrm{AT}$ & $\mathrm{AM}$ & G14 \\
\hline & $M i-H o t^{\mathrm{a}}$ & $\mathrm{OV}$ & $\mathrm{EN}$ & AT & $\mathrm{AM}$ & F14 \\
\hline & $K a-2^{\mathrm{a}}$ & $\mathrm{OV}$ & EN & $\mathrm{AT}$ & $\mathrm{CU}$ & G14 \\
\hline & $C a-8^{\mathrm{a}}$ & $\mathrm{OV}$ & EN & AT & $\mathrm{CU}$ & G14 \\
\hline & Waraniya $^{\mathrm{a}}$ & $\mathrm{OV}$ & EN & AT & $\mathrm{CU}$ & $\mathrm{H} 14$ \\
\hline \multirow{8}{*}{ Elongated short (ES) } & ES1 & TR & EN & $\mathrm{TN}$ & $\mathrm{CU}$ & $\mathrm{H} 14$ \\
\hline & ES2 & LA & $\mathrm{EN}$ & $\mathrm{AT}$ & $\mathrm{CU}$ & G14 \\
\hline & ES3 & LA & EN & $\mathrm{AT}$ & $\mathrm{AC}$ & G14 \\
\hline & ES4 & LA & EN & OB & $\mathrm{CU}$ & G14 \\
\hline & ES5 & LA & $\mathrm{EN}$ & AT & $\mathrm{CU}$ & G14 \\
\hline & ES6 & LA & $\mathrm{EN}$ & AT & $\mathrm{CU}$ & G14 \\
\hline & ES7 & LA & $\mathrm{EN}$ & AT & $\mathrm{AC}$ & $\mathrm{I} 15$ \\
\hline & ES8 & LA & EN & $\mathrm{AT}$ & $\mathrm{CU}$ & G14 \\
\hline
\end{tabular}

${ }^{a}$ Commercial chili pepper cultivars in Sri Lanka

Shape: OV (ovate), LA (lanceolate), TR (triangular); Margin: EN (entire), CR (crenate); Base: TN (truncate), AT (attenuate), OB (oblique); Tip: AM (acuminate), CU (cuspidate), Ac (Acute); Color codes are with reference to the Vejdemo-Johansson et al., (2014) and real colors are given in Figure 3. Fruit orientation is the direction of presentation of fruits to the seed dispersal agents 
Table 4. Pearson's Correlation Coefficients among parameters of leaf size

\begin{tabular}{|l|c|c|}
\hline & Leaf breadth & $\begin{array}{c}\text { Leaf petiole } \\
\text { length }\end{array}$ \\
\hline Leaf length & $0.87^{* * * *}$ & $0.53^{* * * *}$ \\
\hline Leaf breadth & & $0.51^{* * * *}$ \\
\hline$* * * P<0.0001$ &
\end{tabular}

The overall shape of the fruits was significantly different among groups but was not significantly different within the groups $(P<0.05)$. The color of fruits at maturity was around H3 indicating the red color except Bell-pepper which was yellow in color at maturity (C9) (color codes given in VejdemoJohansson et al., 2014). For every genotype, number of locules per fruit, number of fruits per plant at first harvest and the number of seeds per fruit are given in Table 5. Mean total yield at first harvest was also obtained. The yields of genotypes T10, T13, SS1 and SS8 were in the range of chili pepper commercial cultivars in Sri Lanka (100 g or more). Two genotypes of SS and EL and all eight genotypes of ES showed upward orientation of mature fruits and all the other genotypes showed downward orientation of mature fruits. The dendrogram, constructed based on the principal components computed using fruit length, diameter, weight and fruit shape group, identified six main clusters at $72 \%$ of morphological similarity of fruits. Bell-pepper was an out-group, all ES, EL, the other R and $\mathrm{T}$ genotypes clustered separately. SS and SB genotypes were clustered together (Figure 5A of Annexure 2).

\section{Correlation among fruit morphological parameters}

Number of fruits per plant and the height of the plant at maturity were significantly negatively correlated at -0.33 of Pearson Correlation Coefficient $(P<0.001)$ (Table 6 of Annexure 1 and Figure 2). However number of fruits per plant was not significantly correlated with fruit size traits, locule number and seeds per fruit. Highest correlation (Pearson Correlation Coefficient of 0.69) was observed between fruit diameter and fruit weight. Fruit length also showed significant correlation with fruit weight but it was much less (0.27). Seeds per fruit were also significantly correlated with fruit weight (0.61). Plant height was always negatively correlated with fruit size traits, locule number and seeds per fruit $(P<0.001)$ (Table 6 of Annexure 1).

\section{DNA marker analysis Marker polymorphism}

Five microsatellite markers for 49 chili pepper genotypes amplified a total of 44 alleles (Table 7 of Annexure 1). All five markers were polymorphic showing $H$ values ranged from 0.65 to 0.88 and PIC value from 0.62 to 0.87 . The marker GPMS178 exhibited the highest level of polymorphism by displaying 24 alleles, 0.88 of PIC and two unique alleles. Out of the 44 alleles detected, nine alleles were unique, seven alleles were rare and 28 alleles were frequent (Table 7 of Annexure 1).

\section{The relationship of microsatellite marker alleles vs. fruit size and shape}

One marker linked to fruit length, three markers related to fruit diameter and one marker related to fruit shape for Capsicum spp. (Table 1) were used in the study. The marker data for fruit length and diameter were analyzed using ANOVA and the alleles with significant effects on the respective traits were detected (Table 8 of Annexure 1). A total of five alleles were detected for the marker, HpmsE045 (linked to length), and two of these alleles were found to be having significant effects on fruit length $(P<0.05)$. Six alleles of marker CAeMSO10 were found to be having significant effects on fruit diameter. All the alleles with significant effects / associations on the fruit size / shape are listed in Table 8 of Annexure 1. 
A total of 23 alleles were significantly associated with the fruit shape $(P<0.05)$. The marker CAMS493 (the marker linked to fruit shape) yielded seven alleles and all seven alleles were very highly associated with the fruit shape $(P<0.05)$. However none of the alleles detected for marker HpmsE045 linked to length were not associated with the fruit shape $(P<0.05)$ (Table 9 of Annexure 1).

The dendogram was constructed based on the alleles that had significant effects or association with the fruit traits and fruit shape groups respectively (Figure 5B). At $5.4 \%$ genetic similarity coefficient, the genotype Bell-pepper became an out group. The remaining 48 genotypes formed two major clusters at $44.5 \%$ with one cluster having only eight ES genotypes. Remaining 40 genotypes formed two clusters at $55.3 \%$ genetic similarity coefficient. Accessions EL5 and R1 clustered together at $76.5 \%$ of genetic similarity. The cultivars $\mathrm{Ka}-2, \mathrm{Mi}-2, \mathrm{Mi}-\mathrm{Hot}$ and EL1 were also clustered together at $62.7 \%$ of genetic similarity. However other than the clear separation of ES genotypes and Bell-pepper, remaining genotypes were not separately clustered according to their fruit shape groups indicating the possibility of other QTL involve in the determination of fruit size and shape.

The silver stained gel for the marker CAMS451 (which is linked to the fruit diameter) is shown in Figure 6 of Annexure 2. The allele ix (205 bp) was only seen in the accessions and not detected in any of the commercial cultivars. Bell-pepper has a unique allele (allele ii: $240 \mathrm{bp}$ ) indicating that this allele could be relevant to the highest diameter of Bell-pepper. Other than the differentiation of $\mathrm{Mi}-2$ and $\mathrm{Ka}-2$, this marker could be used to differentiate Bell-pepper, $\mathrm{Ca}-8, \mathrm{Mi}$-hot and Waraniya. This marker is special because out of the five markers studied, this is clearly showing the diploid state of alleles and therefore very useful in
QTL mapping and marker assisted breeding given the diploid nature of Capsicum genome.

\section{DISCUSSION}

Ex situ collections of germplasm especially the collections made by the farmers are very important for plant breeding and genetic assessment (Votava et al., 2002). With the rapid deforestation, germplasm is mainly conserved ex situ and to better utilize them, morphological and molecular characterizations are required. According to our morphological results, number of fruits per plant decreases with the plant height indicating that the plants with higher vegetative growth show poor reproductive performance (Peeraullee and Sanmukhiya, 2013). The cluster analysis based on the principal components is very useful as this diversity structure can be used to define genetic core collections, in which minimum number of accessions to represent the highest possible level of variability for conservation efforts. Correlation coefficient values indicate inherent associations among various fruit characteristics. Number of fruits per plant is considered as the most important selection index of fruit yield which was also emphasized by Pawade et al., (1995); Sreelathakumary and Rajamony, (2002). A significant and positive genetic association was also noted between fruit weight and diameter, which was apparent in the morphological results as well (Sarkar et al., 2009; Ullah et al., 2011). The fruit weight was significantly correlated with number of seeds per fruit indicating the seeds may be contributing significantly to weight or more logically affecting the higher growth of mesocarp. Such effects have been reported for Capsicum annuum (Vikram et al., 2014) and for pomegranate (Wetzstein et al., 2011). Leaf and fruit color measurements were recorded using a standard color chart. This kind of approach for measuring color of fruits such as cherry (Sooriyapathirana et al., 2010) 
and apple (Chagné et al., 2007) had been reported. It was interesting to observe that certain Capsicum spp. accessions (T10, T13, SB1, SS1 and SS8) have similar or higher yield compared to that of commercial cultivars grown in Sri Lanka. This strongly suggests that such Capsicum spp. accessions have unused positive alleles that could be used in chili pepper breeding programs. The cluster analysis based on principal components calculated for correlated parameters is the routine practice for morphological diversity analysis (Moskalik et al., 2014). The removal of co-linearity among the variables to be clustered is very important to establish a diversity structure. As depicted in Figure 5A, fruit size and shape related principal components were effective in accurately clustering the genotypes with reference to fruit shape.

Microsatellite markers are extensively used in genetic diversity studies (Hoshino et al., 2012) and QTL mapping studies (Azhaguvel et al., 2006; Collard and Mackill, 2008). These markers are found to be robust and segregating with the important traits such as fruit quality (Kunihisa et al., 2014), yield (Golbadi et al., 2011) and disease resistance (Cerqueira-Silva et al., 2014). The microsatellite markers used in the present study revealed unprecedented diversity for studied germplasm. The marker GPMS178 yielded a PIC value of 0.87 for the chili pepper accessions and cultivars. For the same marker, Nagy et al., (2007) reported 0.89 for Capsicum spp. and 0.78 for $C$. annuum using 33 chili pepper genotypes including cultivated varieties, inbred lines and wild species. This indicates that their studied germplasm has a similar level of diversity compared to the present study.

The ES genotypes were all in one cluster in both fruit morphological and genetic dendrograms suggesting that there size and shape are determined by either different alleles or specialized genetic mechanisms which could be tested using molecular approaches. It is very much evident that Bell-pepper has acquired unique genes through breeding efforts for its commercially appealing size and shape. The marker polymorphism further revealed that there are alleles specific to Capsicum spp. which are absent in the commercial cultivars $(C$. annuum). The effect of alleles on the mean length and diameter of fruits revealed that most of the time the absence of alleles are causing the increased state of the trait value. So that it could be a negative selection inadvertently took place in breeding. Out of the five studied markers, CAMS451 is showing the diploid allelic status thus it is useful in Maker Assisted Selection (MAS) and QTL mapping. It is interesting to note that all the markers were able to amplify alleles in all 49 accessions. Therefore, it is very much possible to use the SSR markers published internationally in local chili pepper breeding and diversity assessment programs.

The present findings strongly suggest that a panel of at least 200 markers (that flank agronomically and industrially important chili pepper QTL) must be verified for successful PCR amplification, clear resolution in gel electrophoresis platforms and for the diploid allelic status using segregating populations such as $\mathrm{F}_{2}$ or recombinant inbred lines (RIL). Then marker alleles and haplotypes could be identified for positive selection of all important traits in breeding. Internationally these kind of efforts have been reported for rice (Yunbi, 2003), beans (Yu et al., 2008), wheat (Miedaner and Korzun, 2012), soybean (Landau-Ellis and Pantalone, 2009), apples (Giongo et al., 2001), potato (Felcher and Douches, 2012) and tomato (Truong et al., 2011). Present study could be used as the initial attempt of validating marker alleles for interested traits and must be followed by further validation of marker genetics through genetic crosses and multi-locational and multiple year trials. The information collected from such an approach would dramatically 
increase the efficiency and accuracy of breeding.

In summary, the morphological and microsatellite marker polymorphism results showed that Capsicum spp. germplasm assessed in this study with respect to commercial chili pepper cultivars showed significantly higher diversity. The microsatellite markers linked to fruit size and shape traits are validated for the polymorphism and the statistical relationship to the fruit traits. Further studies are needed to assess the entire Capsicum germplasm in Sri Lanka using the markers linked to other important QTL such as pest and disease resistance, drought tolerance and the yield components to enable marker assisted breeding for chili.

\section{REFERENCES}

AZHAGUVEL P, SARASWATHI DV, SHARMA A \& VARSHNEY RK. Methodological Advancement in Molecular Markers to Delimit the Gene(s) for Crop Improvement. Floriculture and Ornamental Biotechnology. 2006; 1: 460-469.

BLUM E, MAZOUREK M, O'CONNELL M, CURRY J, THORUP T, LIU K, JAHN M. \& PARAN I. Molecular mapping of capsaicinoid biosynthesis genes and quantitative trait loci analysis for capsaicinoid content in Capsicum. Theoretical and Applied Genetics. 2003; 108: 79-86.

BOSLAND PW \& VOTAVA EJ. Peppers: Vegetable and spice Capsicums. Crop Production Science in Horticulture. 2012; 12: $1-11$.

BOTSTEIN D, WHITE R, SKALNICK MH \& DAVIES RW. Construction of genetic linkage map in man using restriction fragment length polymorphism. American Journal of Human Genetics. 1980; 32: 314331.
CERQUEIRA-SILVA CBM, JESUS ON, OLIVEIRA EJ, SANTOS ESL \& SOUZA AP. Characterization and selection of passion fruit (yellow and purple) accessions based on molecular markers and disease reactions for use in breeding programs. International Journal of Plant Breeding and Genetics. 2014; DOI: $10.1007 / \mathrm{s} 10681-014-1235-9$.

CHAGNÉ D, CARLISLE CM, BLOND C, VOLZ RK, WHITWORTH CJ, ORAGUZIE NC, CROWHURST RN, ALLAN AC, ESPLEY RV, HELLENS RP \& GARDINER SE. Mapping a candidate gene (MdMYB10) for red flesh and foliage colour in apple. BMC Genomics. 2007; 8: 212.

COLLARD BCY \& MACKILL DJ. Markerassisted selection: an approach for precision plant breeding in the twenty-first century. Philosophical Transactions of the Royal Society B. 2008; 363: 557-572.

DAHAL K, SHARMA M, DHAKAL D \& SHAKYA S. Evaluation of heat tolerant chilli (Capsicum annuum L.) genotypes in western terrain of Nepal. Journal of the Institute of Agriculture and Animal Science. 2006; 27: 59-64.

DEPARTMENT OF AGRICULTURE SRI LANKA. Available from: http://www.agridept.gov.lk/index.php/en/ crop-recommendations/1470. 2007; (Accessed: 01 January 2015).

DHANYA K \& SASIKUMAR B. Molecular Marker Based Adulteration Detection in Traded Food and Agricultural Commodities of Plant Origin with Special Reference to Spices. Current Trends in Biotechnology and Pharmacy. 2010; 4: 454-489.

FAO (Food and Agriculture Organization). Available from: http://www.fao.org/home/en. 2014; ([Accessed: 01 January 2015). 
FELCHER KJ \& DOUCHES D. MarkerAssisted Selection for PVY Resistance in Potato. Plant Breeding and Genomic. Available from: http://www.extension. org/pages/32468/marker-assisted-selectionfor-pvy-resistance-in-potato/print/\#. VK1 dviuUf3Q. 2012; (Accessed: 01 January 2015).

GIONGO L, BERGAMINI A, RIGATTI R \& KOMJANC M. Marker assisted selection for scab resistant apple. Acta Horticulturae. 2001; 546: 581-589.

GOLBADI M, ARZANI A, MAILBODY SAMM, TABATABAEI BES \& MOHAMMADI SA. Identification of microsatellite markers linked with yield components under drought stress at terminal growth stages in durum wheat. Euphytica. 2011; 177: 207-221.

HAYMAN M and KAM PCA. Capsaicin: A review of its pharmacology and clinical applications. Current Anaesthesia \& Critical Care. 2008; 19: 338-343.

HOSHINO AA, BRAVO JP, NOBILE PM \& MORELLI KA. Microsatellites as Tools for Genetic Diversity Analysis, Genetic Diversity in Microorganisms. In Prof. Mahmut Caliskan (Ed.), InTech, [Online] Available from http://www.intechopen.com/books/ geneticdiversity-in-

microorganisms/microsatellites-as-tools-forgenetic-diversity analysis. 2012; [Accessed 01 January 2015].

JANG I, MOON JH, YOON JB, YOO JH, YANG TJ, KIM YJ \& PARK HG. Application of RAPD and SCAR markers for purity testing of F1 hybrid seed in chili pepper (Capsicum annuum).Molecules and Cells. 2004; 18: 295-299.

KIM DH \& KIM BD. Development of SCAR markers for early identification of cytoplasmic male sterility genotype in chili pepper (Capsicum annuum L.). Molecules and Cells. 2005; 20: 416-22.

KIM HJ, LEE HR, HAN JH, YEOM SI, HARN CH \& KIM BD. Marker production by PCR amplification with primer pairs from conserved sequences of WRKY genes in chili pepper. Molecules and Cells. 2008; 25: 196204.

KIM S, HWANG JK, KIM KT, KIM DH, YANG EY, CHO MC, JAMAL A, CHAE Y, PAE DH \& OH DG. Identification of Quantitative Trait Loci Associated with Anthracnose Resistance in Chili Pepper (Capsicum spp.). Korean Journal of Horticultural Science \& Technology. 2010; 28: 1014-1024.

KRAFT KH, BROWN CH, NIBHAN GP, LUEDELING E, RUIZ JJL, D'EECKENBRUGGE GC, HIJMANS RJ \& GEPTS P. Multiple lines of evidence for the origin of domesticated chili pepper, Capsicum annuum, in Mexico. Proceeding of National Academic of Sciences. 2014; 111 : 6165-6170.

KUNIHISA M, MORIYA S, ABE S, OKADA K, HAJI T, HAYASHI T, KIM H, NISHITANI C, TERAKAMI S \& YAMAMOTO T. Identification of QTLs for fruit quality traits in Japanese apples: QTLs for early ripening are tightly related to preharvest fruit drop. Breeding Science. 2014; 64: 240-251.

LANDAU-ELLIS, D. \& PANTALONE, V.R. Marker-assisted backcrossing to incorporate two low phytate alleles into the Tennessee soybean cultivar 5601T. Induced plant mutations in the genomics era. Food and Agriculture Organization of the United Nations, Rome (FAO). 2009; 316-318.

LEE H, KIM K, KIM H, HAN J, KIM J, YEOM S, KIM HJ, KANG W, SHI J, PARK, S, BAE I, LEE S, CHO J, OH D \& KIM B. 
QTL analysis of fruit length using rRAMP, WRKY and AFP markers in chilli pepper. Horticulture, Environment, and Biotechnology. 2011; 52: 602-613.

LIU BH. Genomics, Linkage Mapping and QTL Analysis. CRC Press, Boca Raton, Florida. 1998; 661.

MARAME F, DESALEGNE L, FININSA C \& SIGVALD R. Genetic analysis for some plant and fruit traits, and its implication for a breeding program of hot pepper (Capsicum annuum var. annuum L.). Journal of Agricultural and Food Chemistry. 2009; 61: 2530-2537.

MARTÍ, MC, CAMEJO D, VARLLEJO F, ROMOJARO F, BACARIZO S, PALMA JM, SEVILLA F \& JIMÉNEZ A. Influence of fruit ripening stage and harvest period on the antioxidant content of sweet pepper cultivars. Plant Foods for Human Nutrition. 2011; 66: 416-423.

MECKELMANN SW, RIEGEL DW, VAN ZONNEVELD MJ, RÍOS L, PEÑA $K$, UGAS R, QUINONEZ L, MUELLER-SEITZ E \& PETZ M. Compositional characterization of native Peruvian chili peppers (Capsicum spp.). Theoretical and Applied Genetics. 2013; 122: 1051-1058.

MIEDANER T \& KORZUN V. Markerassisted selection for disease resistance in wheat and barley breeding. Phytopathology. 2012; 102: 560-566.

MIMURA Y, INOUE T, MINAMIYAMA Y \& KUBO N. An SSR-based genetic map of pepper (Capsicum annuum L.) serves as an anchor for the alignment of major pepper maps. Breeding Science. 2012; 62: 93-98.

MONTEIRO ER, BRONZATO AR, ORASMO GR, LOPES ACA, GOMES RLF, MANGOLIN CA \& MACHADO MFPS. Genetic diversity analysis of Capsicum spp germplasm bank accessions based on $\alpha / \beta$ esterase polymorphism. Genetics and molecular research. 2013; 12: 1155-1167.

MOSCONE EA, SCALDAFERRO MA, GRABIELE M, CECCHINI NM, SÁNCHEZ GARCÍA Y, JARRET R, DAVIÑA JR, DUCASSE DA, BARBOZA GE \& EHRENDORFER F. The evolution of chili peppers (Capsicum - Solanaceae): Acytogenetic perspective. Acta Horticulturae. 2007; 745: 137-170.

MOSKALIK M, TEGOWSKI J, GRABOWIECKI P \& ZULICHOWSKA M. Principal Component and Cluster Analysis for determining diversification of bottom morphology based on bathymetric profiles from Brepollen (Hornsund, Spitsbergen). Oceanologia. 2014; 56: 59-84.

NAGY I, STAGEL A, SASVARI Z, RODER M \& GANAL M. Development, characterization, and transferability to other Solanaceae of microsatellite markers in pepper (Capsicum annuum L.). Genome. 2007; 50: 668-688.

NAGY S, POCZAI P, CERNÁK I, GORJI AM, HEGEDÜS G \& TALLER J. PIC calc: an online program to calculate polymorphic information content for molecular genetic studies. Biochemical Genetics. 2012; 50: 670672 .

NICOLAI M, CANTET M, LEFEBVRE V, SAGE-PALLOIX A \& PALLOIX A. Genotyping a large collection of pepper (Capsicum spp.) with SSR loci brings new evidence for the wild origin of cultivated $C$. annuum and the structuring of genetic diversity by human selection of cultivar types. Genetic Resources and Crop Evolution. 2013; 60: 2375-2390.

PACHECO-OLVERA A, HERNÁNDEZVERDUGOA S, ROCHA-RAMÍREZB V, GONZÁLEZ-RODRÍGUEZB A \& 
OYAMAB K. Genetic Diversity and Structure of Pepper (Capsicum annuum L.) from Northwestern Mexico Analyzed by Microsatellite Markers. Crop Science. 2012; 52: 231-241.

PAWADE SB, SONTAKE MB, SINDE NN $\&$ BORIKAR ST. Studies on correlation and path analysis for some characters in local chili (Capsicum annuum L.) types from Nagpur district. P K V research journal. 1995; 19: 93-94.

PEERAULLEE N \& RANGHOOSANMUKHIYA VM. Assessment of Genetic Diversity in Local Chilli (Capsicum annuum) Varieties in Mauritius. International Journal of Agriculture and Biology. 2013; 15: 891896.

PERRY L, DICKAU R, ZARRILLO S, HOLST I, PEARSALL DM, PIPERN DR, BERMAN MJ, COOKE RG, RADEMAKER $\mathrm{K}$, RANERE AJ, RAYMOND JS, SANDWEISS DH, SCARAMELLI F, TARBLE K \& ZEIDLER JA. Starch fossils and the domestication and dispersal of chili peppers (Capsicum spp. L.) in the Americas. Science. 2007; 315: 986-988.

PERRY L \& FLANNERY KV. Precolumbian use of chili peppers in the Valley of Oaxaca, Mexico. Proceeding of National Academic of Sciences. 2007; 104: 11905-11909.

QIN C, YUB C, SHENA Y, FANG X, CHEN L, MIND J, CHENG J, ZHAO S, XUD M, LUO Y, YANG Y, WUF Z, MAO L, WUD H, LING-HU C, ZHOU H, LINA H, GONZÁLEZ-MORALES S, TREJOSAAVEDRA DL, TIAN $\mathrm{H}$, TANG $\mathrm{X}$, ZHAO M, HUANG Z, ZHOU A, YAO X, CUI J, LI W, CHEN Z, FENG Y, NIU Y, BI $\mathrm{S}$, YANG $\mathrm{X}$, LI $\mathrm{W}$, CAI $\mathrm{H}$, LUO $\mathrm{X}$, MONTES-HERNÁNDEZ S, LEYVAGONZÁLEZ MA, XIONG Z, HEA X, BAI L, TAN S, TANG X, LIU D, LIU L, ZHANG S, CHEN M, ZHANG L, ZHANG
L, ZHANG Y, LIAO W, ZHANG Y, WANG $\mathrm{M}$, LV $\mathrm{X}$, WEN $\mathrm{B}$, LIUA $\mathrm{H}$, LUAND H, ZHANG Y, YANG S, WANG X, XU J, LI X, LI S, WANG J, PALLOIX A, BOSLAND PW, LID Y, KROGHE A, RIVERA-BUSTAMANTEH RF, HERRERA-ESTRELLAG L, YIND Y, YUB $\mathrm{J}$, HUC J \& ZHANG Z. Whole-genome sequencing of cultivated and wild peppers provides insights into Capsicum domestication and specialization. Proceedings of the National Academy of Sciences. 2014; 111: 5135-5140.

ROSA MM, ANA J, PALOMA R, FELIX R, SIERRA B, MARINA L, MANUEL G, FRANCISCA S, LUIS AR, FRANCISCO JC \& JOSE MP. Antioxidant Systems from Pepper (Capsicum annuum L.): Involvement in the Response to Temperature Changes in Ripe Fruits. International Journal of Molecular Sciences. 2013; 14: 9556-9580.

SAMBROOK J \& RUSSELL D. Molecular Cloning: a Laboratory Manual, $3^{\text {rd }}$ edition. Cold Spring Harbor, New York. 2001; 443.

SARKAR S, FULLER T, AGGARWAL A, MOFFETT A \& KELLEY CD. The Cons Net software platform for systematic conservation planning. In A.MOILANEN, K. A.WILSON, \& H.P.POSSINGHAM, (eds.). Spatial Conservation Prioritization: Quantitative Methods and Computational Tools. Oxford University Press, New York. 2009; 235-248.

SCHUELTER AR, PEREIRA GM, JÚNIOR AAT, CASALI VWD, SCAPIM CA, BARROS WS \& FINGER FL. Genetic control of agronomically important traits of pepper fruits analyzed by Hayman's spatial diallel cross scheme. Genetics and molecular research. 2010; 9: 113-127.

SHETE S, TIWARI H \& ELSTON RC. On estimating the heterozygosity and polymorphism information content value. 
Theoretical Population Biology. 2000; 57: 265-271.

SHIH-WEN L, YU-YU C, HSUEH-CHING $S$, ANDREAS WE, SANJEET K, RAVZA M, ALBERT R, ABDOU T, VICTOR AS \& PAUL AG. Pepper (Capsicum spp.) Germplasm Dissemination by AVRDC - The World Vegetable Center: an Overview and Introspection. Chron Horticult. 2013; 53: 2127.

SOORIYAPATHIRANA S, KHAN A, SEBOLT A, WANG D, BUSHAKRA J, LINWANGK ALLAN A, GARDINER S, CHAGNE D \& IEZZONI A. QTL analysis and candidate gene mapping for skin and flesh color in sweet cherry fruit (Prunusavium L.). Tree Genetics \& Genomes. 2010; 6: 821-832.

SREELATHAKUMARY I. \& RAJAMONY L. Variability, heritability and correlation studies in chilli (Capsicum spp.) under shade. Indian Journal of Horticulture. 2002; 69: 7783.

SUDRÉ CP, LEONARDECZ E, RODRIGUES R, JÚNIOR ATA, MOURA MC \& GONÇALVES LS. Genetic resources of vegetable crops: a survey in the Brazilian germplasm collections pictured through papers published in the journals of the Brazilian Society for Horticultural Science. Horticultura Brasileira. 2007; 25: 496-503.

TRUONG HTH, CHOI H, CHO MC, LEE HE \& KIM JH. Use of $C f-9$ gene-based markers in marker-assisted selection to screen tomato cultivars with resistance to Cladosporium fulvum. Horticulture, Environment, and Biotechnology. 2011; 52: 204-210.

ULLAH MZ, BASHAR MK, BHUIYAN MSR, KHALEQUZZAMAN M \& HASAN MJ. Interrelationship and cause-effect analysis among morpho-physiological traits in biroin rice of Bangladesh. International Journal of Plant Breeding and Genetics. 2011; 5: 246-254.

USMAN MG, RAFII MY, ISMAIL MR, MALEK MA \& LATIF MA. Heritability and genetic advance among chilli pepper genotypes for heat tolerance and morphophysiological characteristics. The Scientific World Journal. 2014; 308042: 14.

VEJDEMO-JOHANSSON M, VEJDEMO S \& EK C. Comparing Distributions of Color Words: Pitfalls and Metric Choices. PLoS ONE. 2014; 9: e89184.

VIKRAM A, WARSHAMANA IK \& GUPTA M. Genetic correlation and path coefficient studies on yield and biochemical traits in chilli (Capsicum annuum L.). International Journal of Farm Sciences. 2014; 4: 70-75.

VOTAVA EJ, NABHAN GP \& BOSLAND PW. Genetic diversity and similarity revealed via molecular analysis among and within an in situ population and ex situ accessions of chiltepin (Capsicum annuum var. glabriusculum) Conservation Genetics. 2002; 3: 123-129.

WANG D \& BOSLAND PW. The Genes of Capsicum. Horticultural Science. 2006; 41: 1169-1187.

WETZSTEIN HY, RAVID N \& WETZSTEIN ME. Characterization of Attributes Related to Fruit Size in Pomegranate. Horticultural Science. 2011; 46: 908-912.

WU KK, BURNQUIST W, SORRELLS ME, TEW TL, MOORE PH \& TANKSLEY SD. The detection and estimation of linkage in polyploids using single-dose restriction fragments. Theoretical and Applied Genetics. 1992; 83: 294-300. 
YAO M, LI N, WANG F \& YE Z. Genetic analysis and identification of QTLs for resistance to cucumber mosaic virus in chili pepper. Euphytica. 2013; 193: 135-145.

YU K, PARKS J \& POYSA V. Markerassisted selection of common beans for resistance to common bacterial blight: efficacy and economics. Plant breeding. 2008; 119: 411-415.
YUNBI X. Developing Marker-Assisted Selection Strategies for Breeding Hybrid Rice. Plant Breeding Reviews, John Wiley and Sons, Inc. 2003; 73. 


\section{ANNEXURE 1.}

Table 5. Yield related parameters in Capsicum genotypes

\begin{tabular}{|c|c|c|c|c|c|c|c|}
\hline $\begin{array}{l}\text { Fruit shape } \\
\text { group }\end{array}$ & Genotype & $\begin{array}{l}\text { No. of locules } \\
\text { per fruit }\end{array}$ & $\begin{array}{l}\text { No. of seeds } \\
\text { per fruit }\end{array}$ & $\begin{array}{l}\text { No. of } \\
\text { fruits* }\end{array}$ & $\begin{array}{c}\text { Mean fruit } \\
\text { weight (g) }\end{array}$ & $\begin{array}{l}\text { Yield at first } \\
\text { harvest (g) }\end{array}$ & $\begin{array}{c}\text { Fruit } \\
\text { orientation }\end{array}$ \\
\hline \multirow{14}{*}{$\begin{array}{l}\text { Triangular } \\
\text { (T) }\end{array}$} & T1 & 2.5 & 16.3 & 10.8 & 3.5 & 37.8 & D \\
\hline & T2 & 2.3 & 24.4 & 15.5 & 4.2 & 65.1 & D \\
\hline & T3 & 2.3 & 16.2 & 8.4 & 3.4 & 28.6 & D \\
\hline & $\mathrm{T} 4$ & 2.6 & 24.4 & 15.9 & 3.0 & 47.7 & D \\
\hline & T5 & 2.6 & 12.2 & 7.5 & 3.0 & 22.5 & D \\
\hline & T6 & 2.4 & 11.4 & 19.0 & 2.3 & 43.7 & D \\
\hline & $\mathrm{T} 7$ & 2.7 & 29.3 & 9.4 & 4.2 & 39.5 & D \\
\hline & T8 & 2.6 & 31.9 & 8.4 & 4.9 & 41.2 & D \\
\hline & T9 & 3.0 & 36.8 & 4.4 & 5.4 & 23.8 & D \\
\hline & T10 & 3.0 & 36.1 & 14.4 & 7.5 & 108.0 & $\mathrm{D}$ \\
\hline & T11 & 3.0 & 37.4 & 14.7 & 3.9 & 57.3 & $\mathrm{D}$ \\
\hline & T12 & 2.9 & 35.3 & 13.5 & 6.0 & 81.0 & D \\
\hline & T13 & 2.8 & 44.1 & 26.7 & 5.2 & 138.8 & $\mathrm{D}$ \\
\hline & T14 & 2.2 & 31.0 & 11.4 & 2.5 & 28.5 & $\mathrm{D}$ \\
\hline \multirow{6}{*}{$\begin{array}{l}\text { Spherical blunt-end } \\
\text { (SB) }\end{array}$} & SB1 & 2.9 & 17.7 & 27.7 & 3.9 & 108.0 & D \\
\hline & SB2 & 3.4 & 33.6 & 26.0 & 2.9 & 75.4 & D \\
\hline & SB3 & 3.3 & 30.5 & 24.0 & 4.5 & 108 & D \\
\hline & SB4 & 3.1 & 25.7 & 18.0 & 3.6 & 64.8 & $\mathrm{D}$ \\
\hline & SB5 & 3.3 & 40.3 & 14.8 & 6.0 & 88.8 & D \\
\hline & SB6 & 2.3 & 28.0 & 25.7 & 3.6 & 92.5 & D \\
\hline \multirow{8}{*}{$\begin{array}{l}\text { Spherical sharp-end } \\
\text { (SS) }\end{array}$} & SS1 & 3.1 & 27.4 & 29.5 & 3.5 & 103.3 & $\mathrm{D}$ \\
\hline & $\mathrm{SS} 2$ & 3.1 & 25.7 & 4.4 & 6.3 & 27.7 & $\mathrm{D}$ \\
\hline & SS3 & 2.6 & 27.3 & 10.5 & 2.6 & 27.3 & $\mathrm{D}$ \\
\hline & SS4 & 2.9 & 31.3 & 40.5 & 4.0 & 16.2 & $\mathrm{D}$ \\
\hline & SS5 & 2.9 & 8.1 & 4.3 & 4.0 & 17.2 & D \\
\hline & SS6 & 2.8 & 31.4 & 14.7 & 6.1 & 89.7 & $\mathrm{D}$ \\
\hline & SS7 & 2.2 & 43.1 & 38.0 & 1.7 & 64.6 & $\mathrm{U}$ \\
\hline & SS8 & 3.0 & 51.9 & 30.4 & 4.6 & 139.8 & $\mathrm{D}$ \\
\hline \multirow{2}{*}{$\begin{array}{l}\text { Rectangular } \\
\text { (R) }\end{array}$} & $\mathrm{R} 1$ & 2.6 & 75.9 & 6.8 & 12.7 & 86.4 & $\mathrm{D}$ \\
\hline & Bell-pepper ${ }^{\mathrm{a}}$ & 3.8 & 105.9 & 6.7 & 37.3 & 249.9 & $\mathrm{D}$ \\
\hline \multirow{11}{*}{$\begin{array}{l}\text { Elongated long } \\
\text { (EL) }\end{array}$} & EL1 & 2.3 & 48.0 & 17.1 & 3.2 & 54.7 & $\mathrm{D}$ \\
\hline & EL2 & 1.9 & 16.5 & 11.6 & 2.3 & 26.7 & $\mathrm{D}$ \\
\hline & EL3 & 2.4 & 32.6 & 7.0 & 2.5 & 17.5 & $\mathrm{D}$ \\
\hline & EL4 & 2.8 & 24.9 & 10.3 & 2.4 & 24.7 & $\mathrm{D}$ \\
\hline & EL5 & 2.2 & 50.2 & 10.1 & 6.3 & 63.6 & $\mathrm{U}$ \\
\hline & EL6 & 2.3 & 67.6 & 9.0 & 5.1 & 45.9 & $\mathrm{D}$ \\
\hline & $M i-2^{\mathrm{a}}$ & 2.0 & 35.3 & 39.5 & 2.1 & 82.9 & $\mathrm{D}$ \\
\hline & $M i-H o t^{\mathrm{a}}$ & 2.1 & 47.1 & 43.3 & 3.0 & 129.9 & $\mathrm{D}$ \\
\hline & $K a-2^{\mathrm{a}}$ & 2.0 & 44.4 & 19.3 & 3.8 & 73.3 & $\mathrm{D}$ \\
\hline & $C a-8^{\mathrm{a}}$ & 2.2 & 54.4 & 8.7 & 10.7 & 93.0 & $\mathrm{D}$ \\
\hline & Waraniya $^{\mathrm{a}}$ & 2.0 & 46.8 & 21.3 & 6.5 & 138.5 & $\mathrm{D}$ \\
\hline \multirow{8}{*}{$\begin{array}{l}\text { Elongated short } \\
\text { (ES) }\end{array}$} & ES1 & 2.0 & 14.1 & 7.3 & 0.4 & 2.9 & $\mathrm{U}$ \\
\hline & ES2 & 2.0 & 12.1 & 9.6 & 0.4 & 3.8 & $\mathrm{U}$ \\
\hline & ES3 & 2.1 & 7.1 & 8.4 & 0.6 & 5.0 & $\mathrm{U}$ \\
\hline & ES4 & 2.0 & 10.2 & 6.7 & 0.5 & 3.2 & $\mathrm{U}$ \\
\hline & ES5 & 2.0 & 15.3 & 13.8 & 0.6 & 8.3 & $\mathrm{U}$ \\
\hline & ES6 & 2.0 & 14.3 & 14.9 & 0.7 & 10.4 & $\mathrm{U}$ \\
\hline & ES7 & 2.0 & 16.3 & 6.2 & 0.7 & 4.3 & $\mathrm{U}$ \\
\hline & ES8 & 2.3 & 27.4 & 17.7 & 1.0 & 17.7 & U \\
\hline
\end{tabular}

${ }^{a}$ Commercial chili pepper cultivars in Sri Lanka

*Number of completely matured fruits at first harvest, D: Downwards, U: Upwards

Table 6. Pearson's Correlation Coefficients $(* * * P<0.001)$ among fruit traits and plant height 


\begin{tabular}{|l|c|c|c|c|c|c|}
\hline & $\begin{array}{c}\text { Fruit } \\
\text { length }\end{array}$ & $\begin{array}{c}\text { Fruit } \\
\text { diameter }\end{array}$ & Fruit weight & $\begin{array}{c}\text { No.of locules } \\
\text { per fruit }\end{array}$ & $\begin{array}{c}\text { No.of seeds } \\
\text { per fruit }\end{array}$ & $\begin{array}{c}\text { Plant } \\
\text { height }\end{array}$ \\
\hline No. of fruits per plant & -0.02 & -0.02 & -0.14 & 0.02 & 0.07 & $-0.33^{* * *}$ \\
\hline Fruit length & & -0.06 & $0.27^{* * *}$ & $-0.26^{* * *}$ & $0.39^{* * *}$ & 0.01 \\
\hline Fruit diameter & & & $0.69^{* * *}$ & $0.58^{* * *}$ & $0.43^{* * *}$ & $-0.45^{* * *}$ \\
\hline Fruit weight & & & $0.35^{* * *}$ & $0.61^{* * *}$ & $-0.28^{* * *}$ \\
\hline No. of locules per fruit & & & & & $0.17^{* * *}$ & $-0.31^{* * *}$ \\
\hline No. of seeds per fruit & & & & & & $-0.27^{* * *}$ \\
\hline
\end{tabular}

Table 7. Microsatellite marker polymorphism in chili pepper accessions

\begin{tabular}{|c|c|c|c|c|c|c|}
\hline Marker & No. alleles / bands & Allele / band (bp) & Allele Frequency & Abundance & $\mathbf{H}$ & PIC \\
\hline \multirow{5}{*}{ HpmsE045 } & \multirow{5}{*}{5} & 190 & 0.08 & FA & \multirow{5}{*}{0.71} & \multirow{5}{*}{0.66} \\
\hline & & 170 & 0.32 & FA & & \\
\hline & & 165 & 0.33 & FA & & \\
\hline & & 150 & 0.01 & UA & & \\
\hline & & 140 & 0.27 & FA & & \\
\hline \multirow{9}{*}{ CAeMSO10 } & \multirow{9}{*}{9} & 350 & 0.03 & RA & \multirow{9}{*}{0.81} & \multirow{9}{*}{0.78} \\
\hline & & 300 & 0.01 & UA & & \\
\hline & & 265 & 0.06 & FA & & \\
\hline & & 255 & 0.07 & FA & & \\
\hline & & 245 & 0.05 & FA & & \\
\hline & & 240 & 0.27 & FA & & \\
\hline & & 235 & 0.09 & FA & & \\
\hline & & 225 & 0.15 & FA & & \\
\hline & & 220 & 0.27 & FA & & \\
\hline \multirow{14}{*}{ GPMS178 } & \multirow{14}{*}{14} & 290 & 0.04 & RA & \multirow{14}{*}{0.88} & \multirow{14}{*}{0.87} \\
\hline & & 300 & 0.21 & FA & & \\
\hline & & 310 & 0.03 & RA & & \\
\hline & & 315 & 0.09 & FA & & \\
\hline & & 320 & 0.05 & FA & & \\
\hline & & 325 & 0.02 & RA & & \\
\hline & & 335 & 0.07 & FA & & \\
\hline & & 338 & 0.06 & FA & & \\
\hline & & 345 & 0.15 & FA & & \\
\hline & & 350 & 0.04 & RA & & \\
\hline & & 355 & 0.16 & FA & & \\
\hline & & 365 & 0.07 & FA & & \\
\hline & & 368 & 0.01 & UA & & \\
\hline & & 380 & 0.01 & UA & & \\
\hline \multirow{9}{*}{ CAMS451 } & \multirow{9}{*}{9} & 250 & 0.015 & UA & \multirow{9}{*}{0.65} & \multirow{9}{*}{0.62} \\
\hline & & 240 & 0.015 & UA & & \\
\hline & & 235 & 0.015 & UA & & \\
\hline & & 232 & 0.091 & FA & & \\
\hline & & 228 & 0.015 & RA & & \\
\hline & & 225 & 0.152 & UA & & \\
\hline & & 223 & 0.136 & FA & & \\
\hline & & 220 & 0.015 & UA & & \\
\hline & & 205 & 0.546 & FA & & \\
\hline \multirow{7}{*}{ CAMS493 } & \multirow{7}{*}{7} & 225 & 0.16 & FA & \multirow{7}{*}{0.84} & \multirow{7}{*}{0.82} \\
\hline & & 220 & 0.15 & FA & & \\
\hline & & 140 & 0.04 & RA & & \\
\hline & & 138 & 0.18 & FA & & \\
\hline & & 135 & 0.17 & FA & & \\
\hline & & 120 & 0.17 & FA & & \\
\hline & & 118 & 0.13 & FA & & \\
\hline
\end{tabular}

FA: Frequent alleles, RA: Rare alleles, UA: Unique alleles 
Table 8. Effect of microsatellite marker alleles on fruit size

\begin{tabular}{|c|c|c|c|c|}
\hline \multirow{2}{*}{ Marker } & \multirow{2}{*}{ Allele / Band (bp) } & \multicolumn{2}{|c|}{ Mean length $(\mathrm{cm})$} & \multirow{2}{*}{$P$ value } \\
\hline & & Allele present & Allele absent & \\
\hline \multirow{2}{*}{ HpmsE045 } & $170^{\mathrm{a}}$ & $4.15^{b}$ & 8.27 & 0.0019 \\
\hline & 165 & 4.24 & 8.40 & 0.0107 \\
\hline & & \multicolumn{2}{|c|}{ Mean diameter $(\mathrm{cm})$} & \\
\hline \multirow{6}{*}{ CAeMSO10 } & 265 & 0.67 & 2.00 & $<.0001$ \\
\hline & 255 & 0.71 & 2.02 & $<.0001$ \\
\hline & 245 & 1.13 & 1.90 & 0.0391 \\
\hline & 240 & 2.06 & 1.34 & 0.0044 \\
\hline & 235 & 0.80 & 2.06 & $<.0001$ \\
\hline & 220 & 1.98 & 1.49 & 0.0611 \\
\hline \multirow{3}{*}{ GPMS178 } & 300 & 2.04 & 1.41 & 0.0109 \\
\hline & 315 & 1.27 & 2.00 & 0.0070 \\
\hline & 355 & 2.13 & 1.50 & 0.0098 \\
\hline \multirow{4}{*}{ CAMS451 } & 240 & 4.90 & 1.75 & 0.0001 \\
\hline & 232 & 0.88 & 1.89 & 0.0222 \\
\hline & 228 & 4.90 & 1.75 & 0.0001 \\
\hline & 220 & 4.90 & 1.75 & 0.0001 \\
\hline
\end{tabular}

${ }^{\mathrm{a}}$ Only the alleles having significant effect $(P<0.05)$ are shown.

${ }^{\mathrm{b}}$ Least square means are indicated.

Table 9. Association of microsatellite marker alleles with fruit shape

\begin{tabular}{|c|c|c|c|}
\hline Marker & Allele (bp) & Chi-square value & $P$ value \\
\hline \multirow{7}{*}{ CAMS493 } & 225 & 32.49 & $<0.0001$ \\
\hline & 220 & 32.49 & $<0.0001$ \\
\hline & 140 & 35.04 & $<0.0001$ \\
\hline & 138 & 29.52 & $<0.0001$ \\
\hline & 135 & 31.92 & $<0.0001$ \\
\hline & 120 & 31.91 & $<0.0001$ \\
\hline & 118 & 21.68 & 0.0006 \\
\hline \multirow{6}{*}{ CAeMSO10 } & 265 & 41.85 & $<0.0001$ \\
\hline & 255 & 49.00 & $<0.0001$ \\
\hline & 240 & 23.51 & 0.0003 \\
\hline & 235 & 38.92 & $<0.0001$ \\
\hline & 225 & 15.66 & 0.0079 \\
\hline & 220 & 24.84 & 0.0001 \\
\hline \multirow{6}{*}{ CAMS451 } & 240 & 23.98 & 0.0002 \\
\hline & 232 & 11.35 & 0.0448 \\
\hline & 228 & 23.99 & 0.0002 \\
\hline & 225 & 16.26 & 0.0061 \\
\hline & 220 & 23.98 & 0.0002 \\
\hline & 205 & 31.62 & $<0.0001$ \\
\hline \multirow{4}{*}{ GPMS178 } & 310 & 12.41 & 0.0295 \\
\hline & 338 & 16.76 & 0.0050 \\
\hline & 355 & 12.40 & 0.0297 \\
\hline & 365 & 14.27 & 0.0140 \\
\hline
\end{tabular}




\section{ANNEXURE 2.}

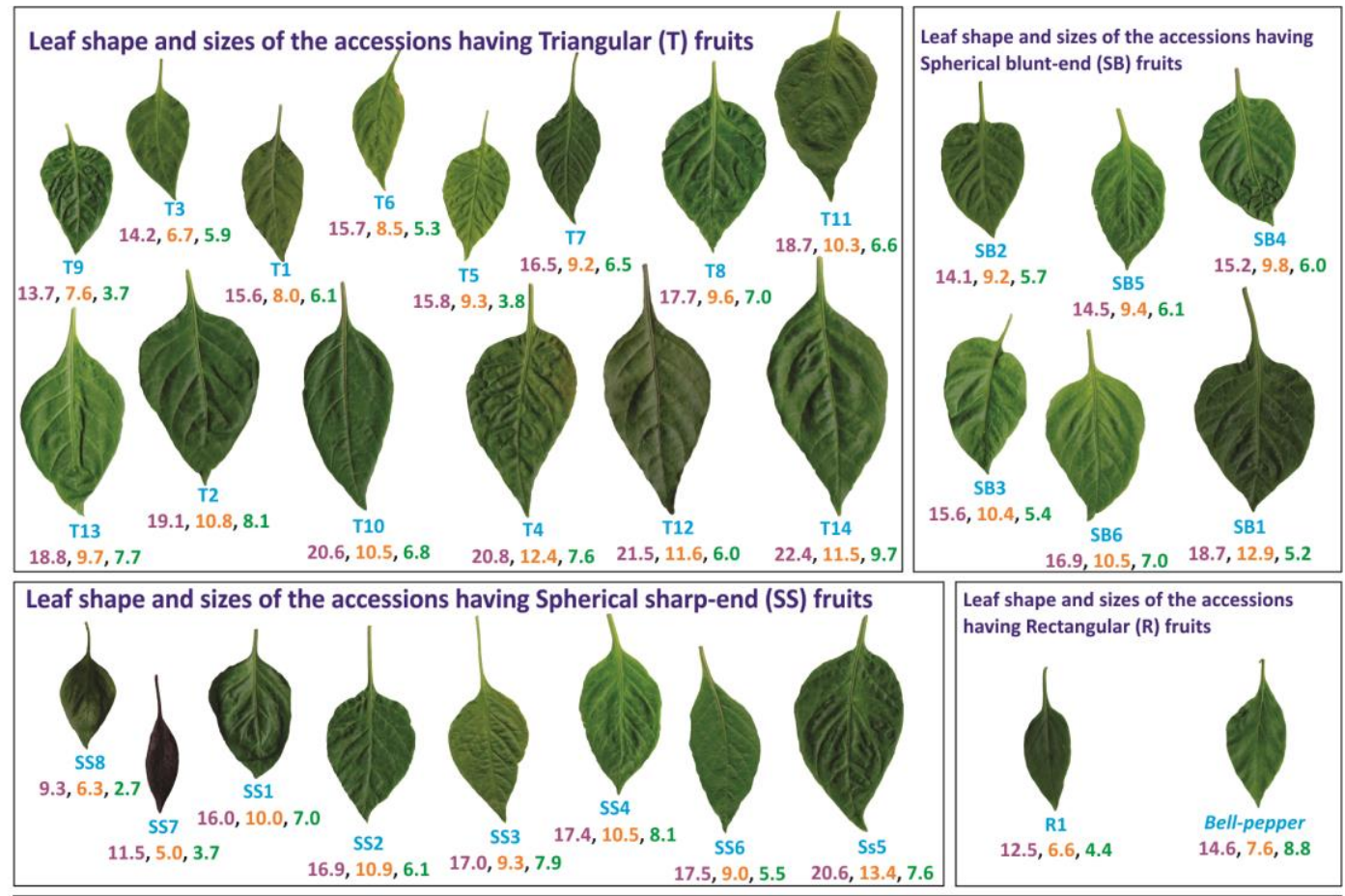

Leaf shape and sizes of the accessions having Elongated long (EL) fruits
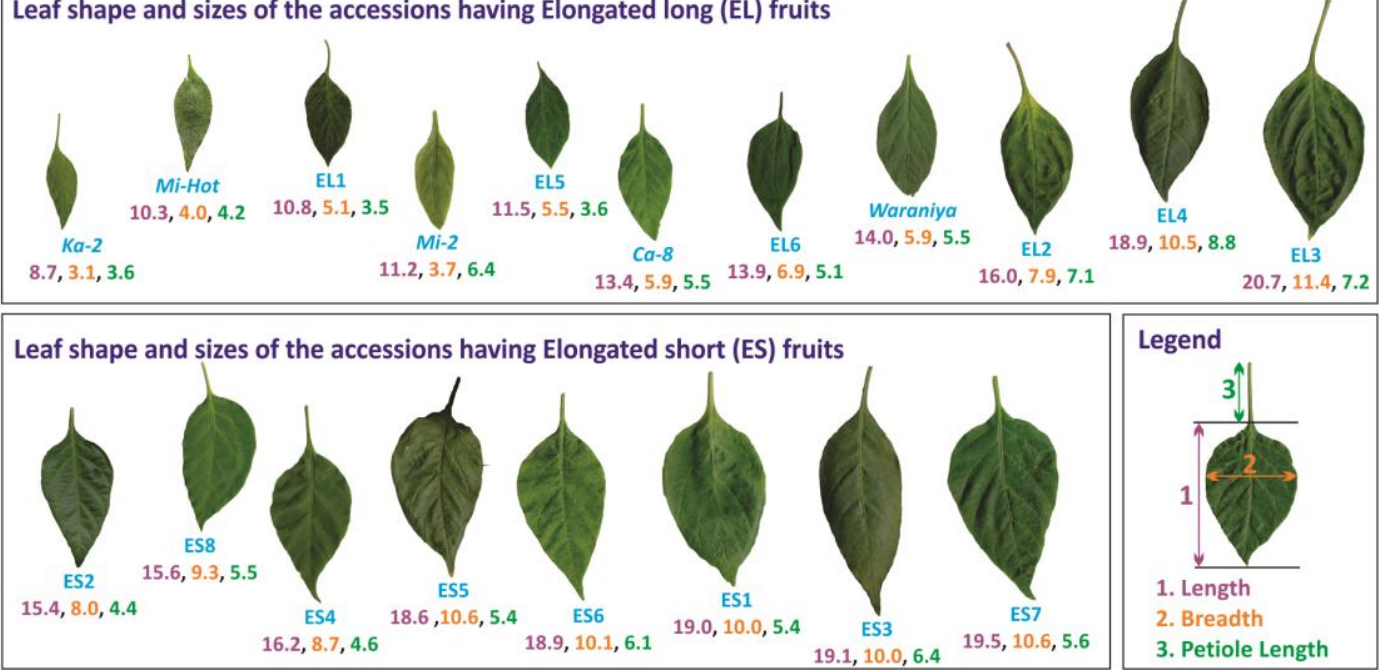

Figure 3 Variation of leaf shape and leaf size in chili pepper accessions and cultivars. The leaves were arranged in to separate boxes based on the six fruit shape groups. The relevant fruit shapes are indicated after the particular fruit shape group. In light blue color names of the Capsicum accessions / cultivars are given beneath the respective leaf tip. Leaf length is shown in purple color, breadth is shown in orange color and petiole length is shown in green color as depicted in the legend located in the bottom right corner of the image. 

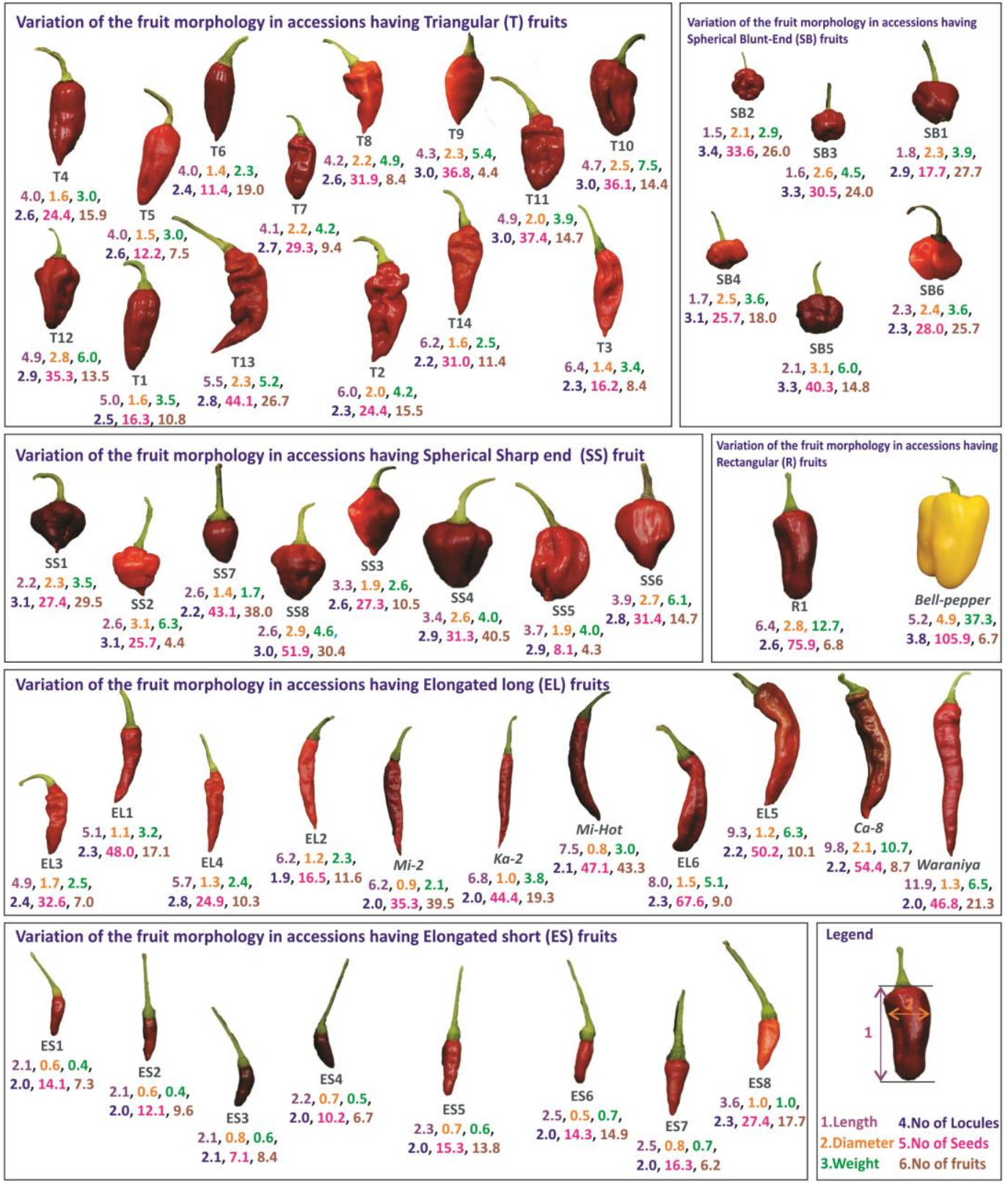

Figure 4 Variation of fruit shape and fruit size in chili pepper accessions and cultivars. The fruits were arranged in to separate boxes based on the six fruit shape groups. The relevant fruit shapes are indicated after the particular fruit shape group. In dark blue color, names of the Capsicum accessions are given beneath the respective fruit. Fruit length is shown in purple color, diameter is shown in orange color, weight is shown in green color, number of locules is shown in blue color, number of seeds is shown in pink color and number of fruits per plant is shown in brown color as depicted in the legend located in the bottom right corner of the image. 


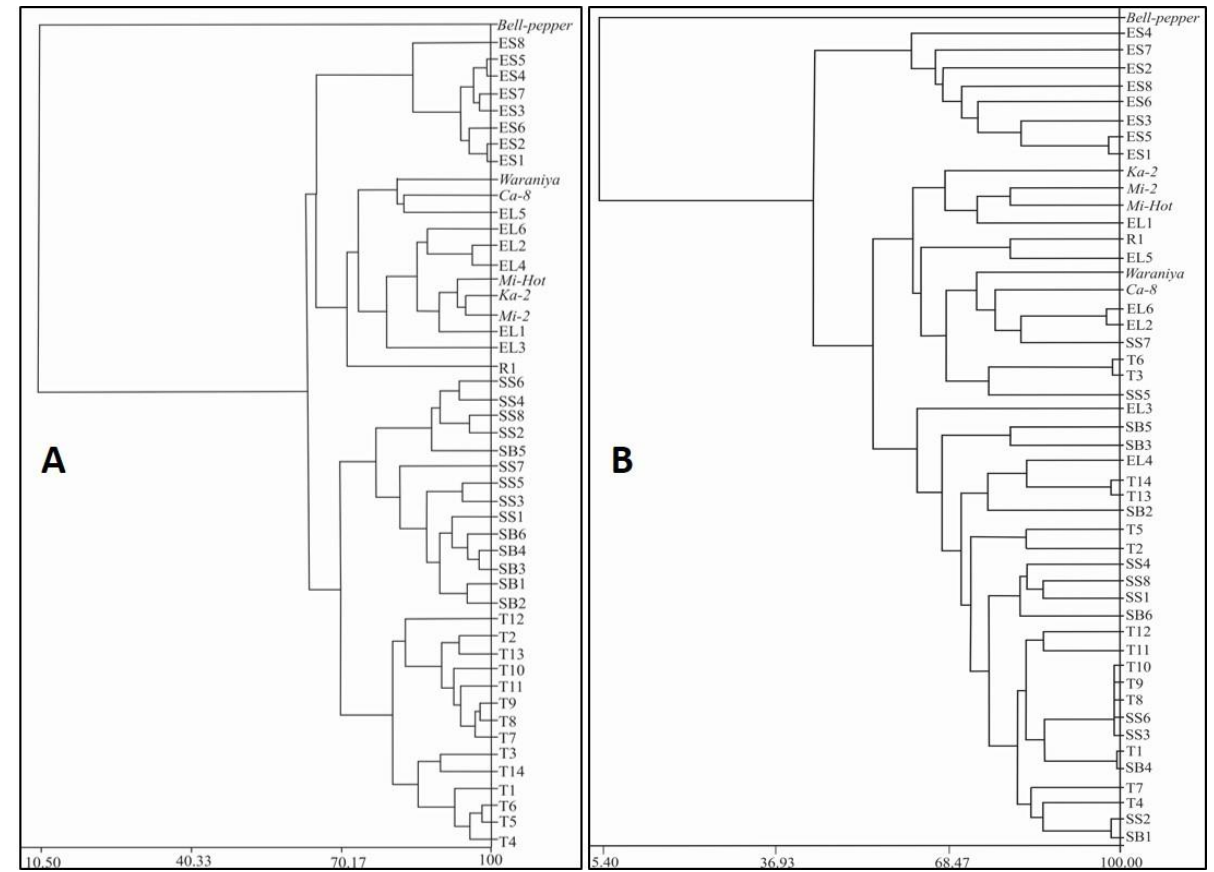

Figure 5. Dendrograms, A: Morphological diversity clustergram constructed based on the principal components computed using fruit length, diameter, weight and fruit shape group. Principal components were computed to remove the co-linearity among parameters. B: Genetic diversity clustergram constructed based on the shape associated allelic data of microsatellite markers. The fruit shape groups are indicated by capital letters and the individual genotype is given by the Arab numeral. T (Triangular); SB (Spherical blunt-end); SS (Spherical sharp-end); EL (Elongated long); ES (Elongated shape) and R (Rectangular) modified from Nicolai et al., (2013). Cluster procedure of average linkage.

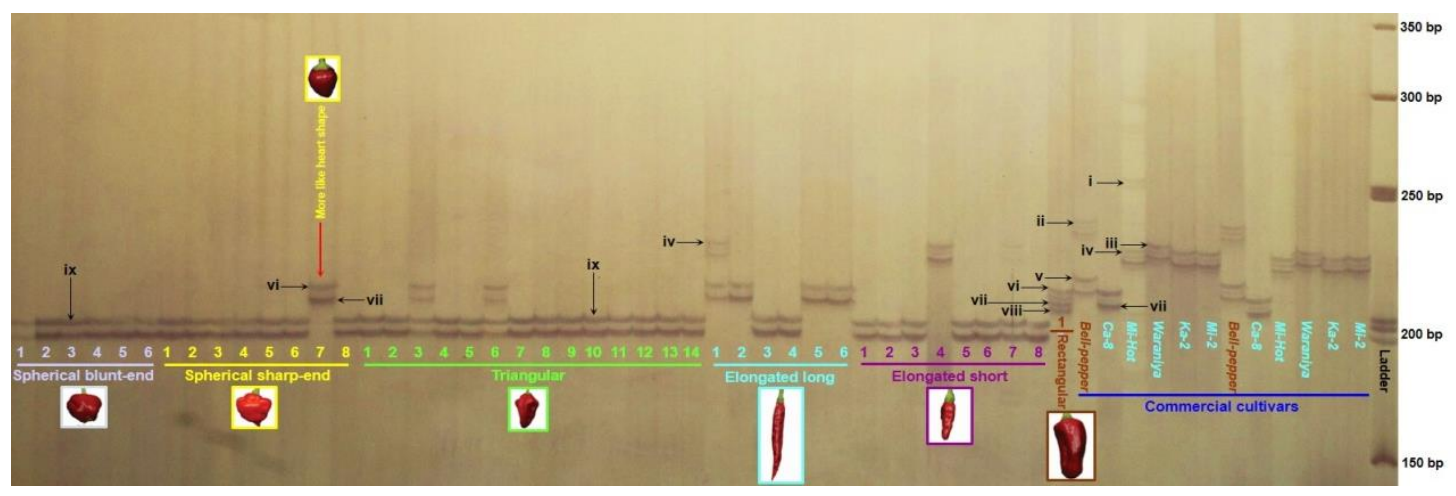

Figure 6. The silver stained polyacrylamide gel image for the microsatellite marker (CAMS451), nine polymorphic alleles were detected and labeled as $\mathrm{i} \rightarrow \mathrm{ix}$ (Roman numbers) the allele sizes are; $\mathrm{i}=250 \mathrm{bp}$, ii $=$ $240 \mathrm{bp}, \mathrm{iii}=235 \mathrm{bp}, \mathrm{iv}=232 \mathrm{bp}, \mathrm{v}=228 \mathrm{bp}, \mathrm{vi}=225 \mathrm{bp}, \mathrm{vii}=223 \mathrm{bp}, \mathrm{viii}=220 \mathrm{bp}, \mathrm{ix}=205 \mathrm{bp}$. The PCR samples were loaded as genotypes assembled into fruit shape groups and indicated with different colors for better visualization. Commercial cultivars were included separately (twice) but the respective colors were used to mark their fruit shape groups. Representative fruit images are showed to indicate the fruit shape groups. Note that SS7 was showing a slightly different phenotype to Spherical sharp-end (SS) which is also showing a different band to the rest of the SS individuals. 50 bp ladder is used for the determination of band sizes. 